\title{
LONG TERM GROUND COVER OPTIONS FOR APPLE ORCHARDS
}

\author{
K.C. HARRINGTON ${ }^{1}$, M.J. HARTLEY ${ }^{2}$, A. RAHMAN ${ }^{3}$ \\ and T.K. JAMES ${ }^{3}$ \\ ${ }^{1}$ Institute of Natural Resources, Massey University, Palmerston North \\ ${ }^{2} 541$ Napier Road, RD 2, Hastings \\ ${ }^{3}$ AgResearch, Ruakura Research Centre, PB 3123, Hamilton \\ Corresponding author: K.Harrington@massey.ac.nz
}

\begin{abstract}
A trial was established in a new Hawke's Bay apple orchard in September 1998 to determine how well various ground cover treatments could control weed competition and influence tree production. Results are presented after six growing seasons. Competition during the first growing season resulted in effects on the trees that were still measurable many years later. Dichondra (Dichondra micrantha) gave a good ground cover for the first few years but slowly regressed to hard-to-control weed species. The red fescue (Festuca rubra) plots survived better than dichondra although also had problems. Bark mulch needed continual assistance from herbicides. Some of the treatments were modified after two growing seasons to investigate establishing ground covers after initially using bark mulches. Results are discussed in terms of using any form of ground cover as a weed control option in orchards, looking at advantages, disadvantages and effects on the weed flora.
\end{abstract}

Keywords: ground covers, mulches, weed control, orchard understorey.

\section{INTRODUCTION}

In recent years there has been some interest in replacing herbicide-treated bare soil strips within apple orchards with low-growing ground covers. The residual herbicides often used to keep soil weed-free are now considered unacceptable by some producer boards. Initial trials by Harrington et al. (1999) and Hartley \& Rahman (1998) showed that dichondra and red fescue are species that may be suitable as ground covers under apple trees for out-competing new weed seedlings. A trial in a young Hawke's Bay apple orchard was started in September 1998 to study the long-term sustainability of such ground cover species, to investigate several ways of establishing them, and to study their effects on apple tree growth and production.

Initial results from the trial were reported by Hartley et al. (2000) after the first growing season. The initial effects of the various treatments on the weed flora were also reported by Harrington et al. (2002). The trial ended in 2004, and this paper reports on final results and conclusions from the trial.

\section{MATERIALS AND METHODS}

Treatments were initially set up by cultivating strips of ground in the HortResearch orchard near Havelock North in September 1998 and planting 1-year-old apple trees (A38R2T119 on MM106 rootstock) $3 \mathrm{~m}$ apart. Plots $9 \mathrm{~m}$ long and $1.8 \mathrm{~m}$ wide were established, each with two trees in the middle and a tree at either end as guard trees.

Treatments were replicated three times in a randomised block design. In one treatment, the soil was left bare for the duration of the trial and sprayed several times each year, mainly with glyphosate (Roundup G2), before weeds became moderately dense. 
In another treatment, any vegetation that established was mown every 1-2 months at a height of $2.5 \mathrm{~cm}$ using a hand-pushed rotary mower, with clippings left on the ground.

Red fescue was established for two treatments (cv. Dawson), with one being mowed as described earlier and the other being both mowed and sprayed periodically with selective herbicides, mainly clopyralid (Versatill) and haloxyfop (Gallant NF). The red fescue for both treatments was resown in April 1999 at $60 \mathrm{~kg} / \mathrm{ha}$ (cv. Sunbreeze) due to poor establishment of the first planting.

Dichondra was established for two treatments in September 1998, with one treatment mown only and the other treatment being both mown and sprayed occasionally with selective herbicides, mainly once a year in late winter with a mixture of haloxyfop, clopyralid and tribenuron (Granstar).

Four other treatments were established with bark mulch, initially laid at a thickness of $15 \mathrm{~cm}$ over corrugated cardboard. Weeds soon established in the mulch, so it was spot-sprayed several times each year with glyphosate, and the bark was reapplied after 2 years to maintain its depth. For one treatment, bark was used for the duration of the trial. In another, dichondra was planted on top of the decomposing bark in August 1999, and then replanted with dichondra in September 2000. The other two bark treatments were cleared of bark in September 2001, with one of these treatments then kept free of vegetation using occasional applications of glyphosate and the other planted with dichondra. All dichondra plots were established by planting $5 \mathrm{~cm}$ diameter plugs of established plants at $23 \mathrm{~cm}$ spacings. The dichondra treatments established in 2000 and 2001 were sprayed with the selective herbicides listed above. Further details of the trial set-up are given in Hartley et al. (2000).

The trunk diameter of trees was measured each winter at a marked position approximately $30 \mathrm{~cm}$ from the ground, and fruit was harvested from each tree in summer and weighed. The percentage of each plot covered by planted species and by each weed species was estimated three to four times each year. An analysis of variance was performed on all data collected.

TABLE 1: Percentage of ground covered by planted species and by weeds in plots beneath apple trees on three occasions during the trial.

\begin{tabular}{lrrrrrr}
\hline & \multicolumn{3}{c}{ \% weed cover } & & \% cover by planted species \\
\cline { 2 - 7 } Treatments & Feb00 & Dec01 & Feb03 & Feb00 & Dec01 & Feb03 \\
\hline Mown volunteer vegetation & 92 & 90 & 97 & NA $^{1}$ & NA & NA \\
Unsprayed dichondra & 67 & 90 & 83 & 40 & 30 & 10 \\
Unsprayed red fescue & 33 & 22 & 37 & 43 & 96 & 93 \\
Bare soil (sprayed) & 1 & 3 & 5 & NA & NA & NA \\
Sprayed dichondra & 10 & 22 & 62 & 90 & 97 & 82 \\
Sprayed red fescue & 27 & 4 & 32 & 72 & 98 & 90 \\
Continuous mulch & 0 & 4 & 8 & NA & NA & NA \\
Mulch with dichondra on top & 1 & 37 & 33 & 2 & 28 & 72 \\
Mulch then cleared to dichondra & 1 & 10 & 33 & NA & 8 & 73 \\
Mulch then cleared to bare soil & 1 & 5 & 15 & NA & NA & NA \\
\hline LSD $(\mathrm{P}<0.05)$ & 7.7 & 12.9 & 30.1 & 23.4 & 21.9 & 21.1 \\
\hline
\end{tabular}

${ }^{1} \mathrm{NA}=$ Not applicable.

\section{RESULTS}

Many of the initial results from this trial have been presented by Hartley et al. (2000), Rahman et al. (2001) and Harrington et al. (2002), so this paper concentrates on the long-term effects of the treatments. 
Constantly mowing plots and applying no herbicides resulted in a sward dominated by perennial grasses, especially perennial ryegrass (Lolium perenne) and prairie grass (Bromus willdenowii), interspersed by some plants of white clover (Trifolium repens), creeping mallow (Modiola caroliniana), creeping oxalis (Oxalis exilis), dandelion (Taraxacum officinale), hawksbeard (Crepis capillaris) and broad-leaved dock (Rumex obtusifolius). A similar sward developed in unsprayed dichondra plots due to the inability of dichondra to out-compete these species without assistance from selective herbicides. However, unsprayed red fescue had considerably fewer weed species present (Table 1) as the red fescue was more competitive, and these plots mainly contained other grass species, hawksbeard and narrow-leaved plantain (Plantago lanceolata).

Constantly spraying the plots with glyphosate resulted generally in invasion by two perennial weed species, namely white clover and creeping mallow, plus a number of different annual species which were occasionally able to set seed prior to the next spraying, including summer grass (Digitaria sanguinalis), redroot (Amaranthus powellii) and black nightshade (Solanum nigrum) in summer, and annual poa (Poa annua), groundsel (Senecio vulgaris), scrambling speedwell (Veronica persica) and hawksbeard in winter. Moss was also well established in these plots by the end of the trial.

Sprayed red fescue plots often looked similar to the unsprayed red fescue, with good swards of red fescue being present in both (Table 1), although most weed species could be removed each winter using selective herbicides. The red fescue was often severely checked if left too long before being mowed, especially if it was then mowed hard and clippings left thickly on the sward. It was generally slow to grow laterally into bare patches.

Dichondra was slow to form dense swards, but once established, it was competitive against weed seedlings that were trying to establish. It was lower growing than red fescue but weeds growing within it resulted in similar fresh weights (FW) being produced. Mowing the plots in the 2002/3 growing season resulted in a mean of $3.0 \mathrm{~kg} \mathrm{FW}$ per plot for sprayed dichondra plots compared with $3.3 \mathrm{~kg}$ for sprayed red fescue plots and $8.0 \mathrm{~kg}$ for the treatment with mown volunteer vegetation $(\operatorname{LSD}(\mathrm{P}<0.05)=1.4)$. Dichondra was susceptible to frost, with densities dropping every winter and not recovering fully until summer, allowing scrambling speedwell and field speedwell (Veronica arvensis) to establish each winter. Dichondra that was established on top of mulch appeared particularly susceptible to frost in winter and moisture stress in summer. The mixture of haloxyfop, clopyralid and tribenuron controlled most weed species within dichondra plots, but over 3-4 years there was a slow build-up of species that were tolerant of these herbicides (Table 1), including creeping mallow, hydrocotyle (Hydrocotyle novaezeelandiae), creeping oxalis, Indian doab (Cynodon dactylon), vulpia (Vulpia bromoides) and grey sedge (Carex divulsa).

For all treatments with vegetation growing close to the base of trees during the first few years of the trial, there were marked decreases in fruit yield and trunk diameter for the duration of the trial (Table 2). The best tree production resulted from constant spraying of the soil, although bark mulch also resulted in good tree growth. Clearing the bark after 3 years then establishing dichondra did not appear to reduce tree growth over subsequent years.

\section{DISCUSSION}

The current standard system of weed control in orchards is to use continual applications of knockdown herbicides, such as glyphosate, to control weeds when they get dense. The treatment within our trial that maintained bare soil using herbicides gave the best tree growth. Although there was a change in weed flora within these plots to species that establish rapidly after spraying, any increase in frequency of spraying that this might cause is less time-consuming than the constant mowing between trees required for ground cover options.

Variability in tree growth for the trial can be seen for the four mulch treatments in 2001 data (Table 2) at which time no clearance of mulch had occurred yet tree growth differed considerably. There was some evidence of tree growth being affected by the presence of mulch during the first few years, presumably due to nitrogen immobilisation, but this 
effect was not consistent. Weed ingress to the bark was surprisingly fast (Harrington et al. 2002), making regular spraying with glyphosate necessary to prevent the weeds competing with the trees.

TABLE 2: Fresh weight of apples harvested from trees in March 2001 and 2003, and mean diameter of tree trunks in June 2001 and 2004.

\begin{tabular}{lcccc}
\hline \multirow{2}{*}{ Treatments } & \multicolumn{2}{c}{$\begin{array}{c}\text { Mean fruit yield } \\
(\mathrm{kg} / \text { tree })\end{array}$} & \multicolumn{2}{c}{$\begin{array}{c}\text { Mean tree diameter } \\
(\mathrm{mm})\end{array}$} \\
\cline { 2 - 5 } & 2001 & 2003 & 2001 & 2004 \\
\hline Mown volunteer vegetation & 4.71 & 24.8 & 42.4 & 86.0 \\
Unsprayed dichondra & 4.04 & 18.3 & 36.1 & 77.6 \\
Unsprayed red fescue & 1.88 & 14.2 & 33.6 & 71.1 \\
Bare soil (sprayed) & 15.55 & 33.4 & 56.0 & 100.3 \\
Sprayed dichondra & 3.87 & 21.8 & 39.1 & 80.4 \\
Sprayed red fescue & 2.02 & 21.4 & 35.7 & 75.1 \\
Continuous mulch & 9.83 & 33.7 & 56.1 & 94.4 \\
Mulch with dichondra on top & 8.39 & 31.1 & 52.8 & 88.5 \\
Mulch then cleared to dichondra & 7.04 & 27.7 & 48.8 & 93.9 \\
Mulch then cleared to bare soil & 12.03 & 33.9 & 58.3 & 97.4 \\
\hline LSD $(\mathrm{P}<0.05)$ & 7.55 & 10.1 & 11.5 & 16.5 \\
\hline
\end{tabular}

Results show that all competition needs to be kept away from trees during the first few years of establishment. However, once trees are established, ground covers appear not to affect tree growth, as shown both by this trial and Harrington et al. (1999).

If ground covers are to be used between trees, measurements of clippings suggest establishing swards of a low growing species rather than just allowing species to establish by themselves will produce significantly less biomass. Presumably this would result in less competition for the trees, although this was not clearly shown by this trial. For species as low-growing as the dichondra, selective herbicides are necessary to stop them being taken over by more aggressive species. However, the current restrictions within Integrated Fruit Production regulations make the use of selective herbicides in ground covers difficult. Tribenuron is not permissible, but clopyralid can be used, and herbicides such as clethodim or sethoxydim could be used instead of haloxyfop. Clopyralid does not control the wide range of weeds removed by tribenuron.

Red fescue is a larger and more competitive plant, making selective herbicides less necessary, and clopyralid and clethodim could be used with red fescue. However, earlier trials have shown how red fescue can reduce production from young trees (Hartley \& Rahman 1998) but not necessarily in older trees (Harrington et al. 1999). Sprayed red fescue appeared less competitive with trees than unsprayed red fescue in this trial, but this was probably due to the red fescue not being planted right to the base of trees in the present trial, and weeds in unsprayed plots subsequently invading the bare soil.

If ground covers are to be used, weeds should be controlled in the first few years using non-selective herbicides or mulches, then ground covers planted once trees are older. Planting on top of decomposing mulch resulted in poor establishment with dichondra as well as with other species not reported in this paper. It is thought that this is due to poor water availability, despite weeds growing prolifically in the mulch. Presumably the weeds got their roots down into the soil more rapidly than planted species. Clearing mulch away gave good establishment of dichondra planted from plugs, but was labour-intensive.

Although creeping species, such a hydrocotyle, creeping oxalis and creeping mallow, became common contaminants within the ground covers, they were not necessarily a problem with respect to competing with trees any more than the planted species. Mixtures 
of such species are probably more sustainable and stable than trying to grow ground-cover species as monocultures. They appeared less competitive than the tall grass species that dominated the unsown, mown treatment.

For ground covers to be a viable alternative to sprayed bare soil strips, an efficient mowing system is required within the tree rows. When frequency of mowing decreased in the final year of the trial, the ground covers soon became overgrown with taller weed species. Although a hand-mower was used in the trial, a tractor-mounted side-arm mower would be essential if ground covers were to be grown in a commercial apple orchard.

Although a detailed analysis of relative costs of the various weed control strategies has not been conducted, the use of glyphosate each year to keep soil bare would probably be cheaper than other treatments. All selective herbicides used are more expensive than glyphosate. Seed costs for both fescue and dichondra are high. More time is required with mowing than spraying, especially if attempting to mow within tree rows, and expensive mowing equipment is required. Bark mulch is also more expensive than using glyphosate alone, even when averaged over the 2-3 year life of the mulch.

\section{ACKNOWLEDGEMENT}

This research was funded by the New Zealand Foundation for Research, Science and Technology. Thanks to Armann Einarsson and other HortResearch staff for assistance in maintaining the trial site.

\section{REFERENCES}

Harrington KC, Hartley MJ, Rahman A, James TK 2002. Strategies for controlling weeds in New Zealand apple orchards. Australian Weeds Conference 13: 208-211.

Harrington K, Zhang T, Osborne M, Rahman A 1999. Orchard weed control from Dichondra micrantha ground covers. Australian Weeds Conference 12:250-254.

Hartley MJ, Rahman A 1998. Use of organic and green mulches in an apple orchard. Proceedings of the New Zealand Plant Protection Conference 47: 320-324.

Hartley MJ, Rahman A, Harrington KC, James TK 2000. Assessing ground covers in a newly planted apple orchard. New Zealand Plant Protection 53: 22-27.

Rahman A, Hartley MJ, Harrington KC, James TK 2001. Use of mulches for weed control in orchards. Proceedings of Asian-Pacific Weed Science Society Conference 18: 295-300. 